\title{
Determinants of Profitability of Islamic Banking Industry: An Evidence from Pakistan
}

\begin{abstract}
Muhammad Mahmood Shah Khan ${ }^{1}$, Farrukh Ijaz ${ }^{2}$, Ejaz Aslam ${ }^{3}$
Abstract

The financial sector plays a vital role in the expansion and growth of an economy. The essential factor for the financial growth of a country is a stable banking system. Over the past few years, Islamic banking industry of Pakistan has grown substantially, however, it faces many challenges regarding its financial stability. This study tries to assess factors that affect the profitability of Islamic banking industry over the period of 2007 to 2014. Return on assets (ROA), return on equity (ROE), and earnings per share (EPS) are used as dependent variables. Bank's size, gearing ratio, non-performing loans (NPL) ratio, operational efficiency, asset composition, asset management, capital adequacy ratio, deposit ratio, gross domestic product (GDP), and consumer price index (CPI) are used as independent variables. Findings of the study indicate that measures of Islamic banking profitability are significantly affected by bank-specific factors such as gearing ratio, asset management, deposit ratio, and NPL ratio and external factor such as CPI.
\end{abstract}

Keywords: Islamic Banks, Profitability, Return on Assets, Return on Equity, Earnings per Share, Pakistan.

\section{Introduction}

An economy can achieve stability if it designs and implements sustainable policies regarding its economic system. Certain changes have been observed in financial banking system of Pakistan due to privatization of public commercial banks, ongoing process of mergers, and introduction of Shariah based banking system after 1997. The financial sector of Pakistan consists of development financial institutions (DFI's), commercial banks, specialized banks, non-banking finance companies (NBFC's), microfinance banks, investment banks, house finance companies (HFC's), leasing companies, and mutual funds and modarabas. The financial sector of Pakistan comprises of national and foreign financial institutions. The State Bank of Pakistan (SBP) is responsible for supervision and regulations of these commercial banks and DFI's, whereas all other financial institutions are monitored and regulated by the Securities and Exchange Commission (SECP) of Pakistan (State Bank of Pakistan [SBP], 20074).

Islamic banking is one of the most recent area in worldwide financial business.

1 Director, Institute of Islamic Banking, University of Management and Technology, Lahore. 2 Academics Officer, Institute of Islamic Banking, University of Management and Technology, Lahore. 3 PhD Scholar, Institute of Islamic Banking, University of Management and Technology, Lahore. 4 http://www.sbp.org.pk/ibd/bulletin/2007/Feb-Bulletin.pdf 
Since the last decade, the expansion of Islamic banking in Pakistan and around the globe is considerable and is gaining acceptance in the entire world. According to SBP, growth rate of Islamic banks is $27 \%$ in total assets and $33.3 \%$ in deposits for the last couple of years (SBP, 2014). Therefore, it is principally important to explore the factors that may impact profitability of Islamic banks and promote execution for further improvement on the premise of gainfulness. Although, there are number of variables which influence Islamic banks' profitability, yet the most widely recognized is monetary proportions ${ }^{5}$. Considering Islamic banking a new dimension in Pakistan economic framework, the industry needs to know about the key factors that could enhance their profitability. This research paper attempts to identify important factors that have an impact on Islamic banking sector's profitability in Pakistan. The principle aim of this investigation is to figure out how bank specific and environment specific factors influence the profitability of Islamic banks in Pakistan.

The objective of the study is to examine the key internal and external factors that impact the profitability of Islamic banking system in Pakistan. This study is important because it is conducted in an area which is unexplored in the context of an emerging economy, i.e. Pakistan. Besides, it is comprehensive in the sense that a number of internal and external factors (as stated by the study) have been used to check their potential impact on the profitability of Islamic banks' profitability, that eventually allow Islamic bank's management and regulatory bodies to control/steer these factors in their favor.

The research paper is composed of four sections. Section 1 provides the significance and objective behind conducting the study. Section 2 provides a background of the existing research studies, relating bank profitability to its determinants that have been stated to formulate the current research hypothesis. Section 3 describes research methodology; data, variables and research method of the study. Section 4 presents findings of the study. Conclusion is offered in the final section.

\section{Literature Review}

Islamic banking plays equally a vital role in the economic development of an economy like other financial institutions. It has changed the perspective of investors and lenders. In recent time periods, improvements in Islamic banking have made significant financial meditation in the financial world. The financial products offered

5 Monetary proportion is a change in the proportion of total assets that banks must hold in reserve with the central bank. Banks only maintain a small portion of their assets as cash available for immediate withdrawal; the rest is invested in illiquid assets like mortgages and loans. By changing the proportion of total assets to be held as liquid cash, the central bank changes the availability of loanable funds. This acts as a change in the money supply. Central banks typically do not change the reserve requirements often as it can create volatile changes in the money supply and may disrupt the banking system. 
by this emerging industry are among the most progressively utilized in recent years (Abu Hussain \& Al-Ajmi, 2012). Today, Islamic banks are useful all over the world and perform in various capacities to give their clients a mixture of administrations, business credits, and speculation items. The idea of Shariah compliant banking is acknowledged in Muslim as well as non-Muslim countries. However, given that Pakistan is a Muslim nation, its Islamic banks' market share in the financial industry is still moderately little, i.e. $14.8 \%$ as of June 15, 2015 (SBP, 2015 $)$ despite around $28 \%$ for the year 2012-2013 (SBP, 20136).

The determinants of profitability in Islamic banking industry are investigated in several studies (Naceur \& Goaied, 2001; Abreu \& Mendes, 2002; Hassan \& Bashir, 2003; Kosmidou \& Zopounidis, 2008; Riaz, 2013; Almazari, 2014; Ostadi \& Monsef, 2014; Ijaz, Akmal, \& Gillani, 2015). In past, analysts have attempted to discover the determinants of profitability for banking sector. However, few scholars considered only internal banking characteristics in their studies, which are in control of bank management (Haslem, 1968; Short, 1979; Lin, 1988; Bourke, 1989; Lloyd-Williams, Molyneux, \& Thornton, 1994; Naceur \& Goaied, 2001; Athanasoglou, Delis, \& Staikouras, 2006; Flamini, Schumacher, \& McDonalid, 2009; Ostadi \& Monsef, 2014, Ijaz, Akmal \& Gillani, 2015), while others incorporated the external uncontrollable factors (Short, 1979; Bourke, 1989; Molyneux \& Thornton, 1992; Iqbal \& Molyneux, 2004; Riaz, 2013).

Internal determinants of bank profitability can be defined as those variables that are influenced by the bank's management decisions and policy objectives. The internal variables mostly employed are liquidity ratios, asset portfolio, net profit margin, earnings, overhead costs and capital ratios. External determinants of bank profitability are concerned with those factors which are not influenced by specific bank's decisions and policies, rather by events outside the influence of bank. External variables consist of premium rate, business sector structure, gross domestic product, inflation, regulation, and business sector development growth. Most of previous studies are conducted on the banking sector of developed economies, leaving only few studies focusing on emerging economies, for example, Pakistan (Burki \& Niazi, 2010; Riaz, 2013; Ijaz et al. 2015).

Various studies have been conducted to identify determinants of profitability of banks in different countries. Naceur and Goaied (2001) reported banks' portfolio structure, capitalization, work efficiency and capital profitability to be the significant determinants of Tunisian banks' performance over the period 1980-1995. Abreu and Mendes (2002), for the time period from 1986-1999, studied four European Union

6 http://www.sbp.org.pk/ibd/bulletin/2015/IBB-Jun-2015.pdf

7 http://www.sbp.org.pk/ibd/bulletin/2013/IBB-Dec-2013.pdf 
nations. They checked the impact of bank-specific and business sector variables on its profitability. They reported an impact of labor and assets on net interest margin (NIM) only, whilst bank market share and unemployment rate are relevant for explaining ROA and ROE. Chirwa (2003) examined the profits of commercial banks in Malawi, utilizing data from 1970 to 1994 . He found a positive relationship between market fixation and profits of banks. Bashir (2003) investigated the determinants of profitability in 14 Islamic banks of 8 nations (i.e., UAE, Egypt, Kuwait, Jordan, Bahrain, Sudan, Qatar and Turkey) for the period 1993-1998, utilization ROA and ROE as dependent variables. The OLS regression reported that high capital-to-asset and loan-to-asset ratios lead to higher profitability. The regression results also found that implicit and explicit taxes affect the bank profitability negatively. Goddard, Molyneux, and Wilson (2004) reported that bank size has a positive effect on the bank's overall performance by applying panel and cross-sectional regression models.

Al-Tamimi (2005) studied the determinants of UAE banks' profitability for the period from 1987-2002. He found that the banks' portfolio and size have statistically significant impact on performance and profitability (ROA and ROE). Alkassim (2005) studied the profitability of Islamic and conventional banks in Gulf Cooperation Coun$\mathrm{cil}^{8}$ (GCC) countries over the time period 1997-2004. He considered both internal (asset quality, capitalization, work efficiency, total expenses) and external (interest, industry structure, and regulations)factors as determinants of profitability (ROA, ROE and NIM) and reported that conventional banks have better asset quality as compared to Islamic banks. However, Islamic banks are better capitalized. The empirical results also suggested that interest-free lending in Islamic banking advocate profitability.

Athanasoglou et al. (2006) measured effects of selected determinants on banks profitability in the South Eastern European (SEE) region from 1998 to 2002 period. The study found a positive relationship of concentration and inflation on the bank profitability, whereas banks' profits were not significantly affected by real GDP fluctuations. Wum et al. (2007) investigated the impact of banks' age, banks size, financial change, the level of monetization, non-interest ratio, extent of capitalization level and GDP per capita on the profitability of 14 Chinese banks from 1996 to 2004. The results showed that the higher the levels of financial change, the better ROA for banks. The results exhibited a negative impact of per capita GDP and a longer bank existence on the ROA. On the other hand, a negative impact of size and business presentation on the ROA was also found.

8 Gulf Cooperation Council (GCC) is a political and economic alliance of six Middle Eastern countries - Saudi Arabia, Kuwait, the United Arab Emirates, Qatar, Bahrain, and Oman, to achieve unity among its members based on their common objectives and their similar political and cultural identities, which are rooted in Islamic beliefs. 
Kosmidou and Zopounidis (2008) measured the Greek banks' performance from 1990 to 2002 utilizing ROA as a explained variable, while cost to income ratio, the proportion of equity to total assets, the proportion of loans to customers and shortterm financing, the proportion of ratio of loan loss reserves to gross loans, the bank's total assets accounting value (bank size), the annual change in GDP, inflation rate, growth of the money supply, stock market capitalization, and the proportion of ratio total assets of the deposit money banks divided by the GDP considered as explanatory variables. The study showed that the effect of bank size and the annual change in GDP were positive, while inflation rate had a critical negative effect on the performance.

Sufian and Habibullah (2009) focused on the internal and external factors that influence profitability of banks in Thailand from 1999 to 2005. ROA and ROE were used as dependent variables. The study concluded that bank size, economic growth, and capitalization have positive impact on profitability whereas non-interest income, per capita GDP, credit risk and overhead costs have negative relationship with profitability of banks. Singh and Chaudhary (2009) studied the determinants of Indian banks and foreign banks from 2001 to 2007 and reported that investments, per capita income, index of industrial production, wholesale price index, foreign exchange reserves, and exports have positive impact on profitability of Indian and foreign banks; whereas the advances, deposits, and assets have no impact on Indian public sector banks' profitability and there is a positive impact on private sector and foreign banks' profitability.

Flamini et al. (2009) used data of different variables from 389 banks of 41 Sub-Saharan African nations and demonstrated that alongside the credit risk, banks' ROA are connected with bigger bank size. Further, banks' profits are influenced by the macroeconomic determinants which are regulations, market power, and systematic risk. Burki and Niazi (2010) inspected the impact of cash related changes on the profitability of banks of Pakistan while using data of 40 banks for the period of 1991-2000 and found that banks size, deposit ratios, and interest picking up ratios affect efficiency and performance of banks. Aburime (2010) measured the impact of corruption on the profitability of Nigerian banks for the time period from 1996 to 2006. He found a positive and statistically significant influence of corruption on the banks profitability.

Anber and Alper (2011) provided empirical evidence on the effect of bank specific variables in addition to macroeconomic indicators on profitability of 10 commercial banks listed on Istanbul stock exchange from 2002 to 2010. They reported a positive and significant effect of asset size and non-interest income on banks' profitability, whereas banks' credit portfolio size and loans under follow-up impact negatively on the profitability. The premium rate (real interest rate) also had a positive influence 
on the banks' profitability in Turkey. Olson and Zoubi (2011) compared accounting profitability measures of banks with the economic determinants in the 10 countries of Middle East and North African (MENA) regions from 2000 to 2008. ROA and ROE were used as proxies for accounting profitability and economic determinants were cost and benefit efficiencies. The study concluded that bank size has a positive effect on the banks accounting measures of profitability. It was also found that there is a negative impact of cost efficiency on the profitability.

Ostadi and Monsef (2014) focused on the factors influencing the profitability of business banks in Iran. Dependent variable was profitability (measured by ROE, ROA), and bank deposits, bank size, bank capital, liquidity concerns, and keeping money prerequisites were independent variables. Results showed that the bank size and bank concentration significantly influence banks profitability. Ijaz et al. (2015) investigated the influence of banks internal factors on the profitability of Islamic banks in Pakistan during 2006 to 2013. Bank size, gearing ratio, operational efficiency, asset management, and capital adequacy ratios were used as independent variables. ROA and ROE were used as a proxy for dependent variable (profitability).

The above discussion confirms that there are strong linkages among the profitability of banks and its internal and external factors as identified by several research studies. However, results varied significantly due to the differences in institutional setting and data included in the analysis. Summarizing the results from numerous studies, various measures of costs are generally negatively correlated with profits.

\subsection{Research Hypothesis}

Following research hypothesis are established on the basis of previous literature.

$\mathrm{H}_{1}$ : There is a significant impact of internal factors on the profitability of Islamic banks.

$\mathrm{H}_{1 \mathrm{a}}$ : There is a positive relationship between size and bank's profitability.

$\mathrm{H}_{11}$ : There is a positive relationship between gearing ratio and bank's profitability.

$\mathrm{H}_{1 \mathrm{c}}$ : There is a positive relationship between asset management and bank's profitability.

$\mathrm{H}_{1 \mathrm{~d}}$ :There is a negative relationship between deposit ratio and bank's profitability.

$\mathrm{H}_{1 \mathrm{e}}$ : There is a negative relationship between NPL's ratio and bank's profitability.

$\mathrm{H}_{1 \mathrm{f}}$ : There is a positive relationship between asset composition and bank's profitability. 
$\mathrm{H}_{1:}:$ There is a positive relationship between capital adequacy ratio and bank's profitability.

$\mathrm{H}_{1 \mathrm{~h}}$ : There is a positive relationship between operating efficiency and bank's profitability.

$\mathrm{H}_{2}$ : There is a significant impact of external factors on the profitability of Islamic banks

$\mathrm{H}_{2 \mathrm{a}}:$ There is a positive relationship between GDP and bank's profitability.

$\mathrm{H}_{26}$ : There is a negative relationship between CPI and bank's profitability.

\section{Data and Methodology}

\subsection{Sample and Data Collection}

The population of this study is Islamic banks of Pakistan. The sample is a balanced panel dataset of five Islamic banks, covering a time period 2007 to 2014, consisting of 40 observations. An advantage of using panel data is that more observations on the explanatory variables are available (Hsiao, 2007). Sample consists of five banks i.e., Meezan Bank Limited, Burj Bank Limited, Dubai Islamic Bank Limited, Bank Islami Pakistan Limited, and Al-Baraka (Pakistan) Bank Limited. The selected banks constitute a major and most prominent part in Shariah compliant financing during the period under review in Pakistan. The data on internal variables are collected from annual reports of selected banks, whereas the data on external macroeconomic variables are collected from the website of World Bank ${ }^{9}$. A total of 8 internal variables and 2 external variables are used for the research study on annual basis.

\subsection{Research Variables}

The profitability of Islamic banks is measured by three dimensions, i.e. return on assets, return on equity, earnings per share. Internal explanatory variables include bank size, gearing ratio, asset management, deposit ratio, non-performing loans ratio, asset composition, capital adequacy ratio and operating efficiency, whereas external explanatory variables include gross domestic product (GDP) and consumer price index (CPI).

\subsubsection{Bank Specific Independent Variables}

- Banks Size: In most of the financial literature, bank size is represented by the

9 www.worldbank.org 
total assets of the banks. Natural logarithm of total assets is used as a proxy for bank size. The effect of bank size on profitability is generally expected to be positive (Smirlock, 1985).

- Gearing Ratio: Gearing ratio is measured by the total liabilities divided by the total equity of the banks. Earlier studies suggest that the impact of gearing ratio is positive on the profitability.

- Asset Management: Asset management is basically the management of bank client investments. It is represented by operating efficiency divided by total assets. A bank with higher asset management ratio leads to enhancing profitability.

- Deposit Ratio: Deposit ratio is the ratio of total deposits to total assets which is another liquidity indicator. The deposits are an important source for bank's funding. Increase in the deposits transformation into loans also increases profitability (Anbar \& Alper, 2011).

- Non-Performing Loans: A non-performing loan is a loan that is in default or close to being in default. It is measured by the value of nonperforming loans to the total value of the loan portfolio. An increase in non-performing loans ratio leads to decrease in profitability of the banks.

- Asset Composition: Asset composition is explained by total liabilities (loans) divided by total asset, provides a measure of income source and measures the liquidity of bank assets tied to loans. This variable is included in the study as an independent variable to determine the impact of loans on banks' profitability.

- Capital Adequacy Ratio: The ratio of capital to risk weighted assets is a ratio of bank's capital to risk. It shows the ability of bank to absorb losses and handle risk exposure with shareholders. This ratio is expected to have positive relation with profitability (Berger \& Ofek, 1995; Hassan \& Bashir, 2003).

- Operating Efficiency: The capability of an enterprise to deliver products / services to its customers in the most cost-effective manner possible and is calculated as total operating expenses divided by total assets

\subsubsection{Macroeconomic Independent Variables}

Gross Domestic Product: It measures the growth in the economic activities after adjustment of inflation. The study has taken annual GDP of the country.

Consumer Price Index: It measures the increase in the overall percentage in consumer price index annually for all goods and services. 
Table 1: Definitions and Notations of the Variables

\begin{tabular}{|c|c|c|c|}
\hline Variable & Symbol & Measure & Reference \\
\hline $\begin{array}{l}\text { Return on } \\
\text { Asset }\left(\mathrm{Y}_{1}\right)\end{array}$ & $\mathrm{ROA}$ & $\begin{array}{l}\text { Annual net income / } \\
\text { Average total assets }\end{array}$ & $\begin{array}{l}\text { Hassan \& Bashir, 2003; Siddiqui, 2008; } \\
\text { Kosmidou \& Zopunidis, 2008; Sufian \& } \\
\text { Habibullah, 2009; Ostadi \& Monsef, } 2014\end{array}$ \\
\hline $\begin{array}{l}\text { Return on } \\
\text { Equity }\left(\mathrm{Y}_{2}\right)\end{array}$ & ROE & $\begin{array}{l}\text { Annual net income / } \\
\text { Average total equity } \\
\end{array}$ & $\begin{array}{l}\text { Hassan \& Bashir, 2003; Alkassim, 2005; Ol- } \\
\text { son \& Zoubi, 2011; Ostadi \& Monsef, } 2014\end{array}$ \\
\hline $\begin{array}{l}\text { Earnings per } \\
\text { Share }\left(\mathrm{Y}_{3}\right)\end{array}$ & EPS & $\begin{array}{l}\text { Net income / No. of } \\
\text { shares }\end{array}$ & $\begin{array}{c}\text { Brigham \& Houston, 2009; Uddin, 2009; } \\
\text { Raza, } 2010\end{array}$ \\
\hline Banks Size (X1) & SIZE & Log of total assets & $\begin{array}{l}\text { Smirlock, 1985; Goddard et al. 2004; Al- } \\
\text { Tamimi, 2005; Wum et al., 2007; Flamini et } \\
\text { al. } 2009\end{array}$ \\
\hline $\begin{array}{l}\text { Gearing Ratio } \\
\left(\mathrm{X}_{2}\right)\end{array}$ & GR & $\begin{array}{c}\text { Total liabilities / } \\
\text { Total equity } \\
\end{array}$ & Wum et al., 2007 \\
\hline $\begin{array}{l}\text { NPL's Ratio } \\
\qquad\left(\mathrm{X}_{3}\right)\end{array}$ & NPL & $\begin{array}{c}\text { Non-performing loans } \\
/ \text { Total loans }\end{array}$ & Anbar \& Alper, 2011 \\
\hline $\begin{array}{l}\text { Asset Composi- } \\
\text { tion }\left(\mathrm{X}_{4}\right) \\
\end{array}$ & $\mathrm{AC}$ & $\begin{array}{c}\text { Total liabilities / } \\
\text { Total assets } \\
\end{array}$ & Wum et al., 2007; Ostadi \& Monsef, 2014 \\
\hline $\begin{array}{l}\text { Asset Manage- } \\
\text { ment }\left(\mathrm{X}_{5}\right)\end{array}$ & $\mathrm{AM}$ & $\begin{array}{c}\text { Operating income / } \\
\text { Total assets } \\
\end{array}$ & Kosmidou \& Zopunidis, 2008 \\
\hline $\begin{array}{c}\text { Operational } \\
\text { Efficiency }\left(\mathrm{X}_{6}\right)\end{array}$ & $\mathrm{OE}$ & \begin{tabular}{|c|} 
Operating expenses / \\
Total assets \\
\end{tabular} & Naceur \& Goaied, 2001 \\
\hline $\begin{array}{c}\text { Deposit Ratio } \\
\left(\mathrm{X}_{7}\right)\end{array}$ & DR & \begin{tabular}{|c|} 
Total Deposits / Total \\
assets
\end{tabular} & $\begin{array}{l}\text { Hassan \& Bashir, 2003; Anbar \& Alper, } \\
2011\end{array}$ \\
\hline $\begin{array}{l}\text { Capital Ade- } \\
\text { quacy }\left(\mathrm{X}_{8}\right)\end{array}$ & CAR & $\begin{array}{l}\text { Tier I + Tier II capital } \\
\text { / Risk weighted assets } \\
\end{array}$ & $\begin{array}{c}\text { Berger \& Ofek, 1995; Hassan \& Bashir, } \\
\text { 2003; Burki \& Niazi, } 2010\end{array}$ \\
\hline $\begin{array}{c}\text { Gross Domestic } \\
\text { Product }\left(\mathrm{X}_{9}\right)\end{array}$ & GDP & Annual GPD & $\begin{array}{l}\text { Molyneux \& Thornton, 1992; Demir- } \\
\text { guc-Kunt \& Huizinga, 1999; Wum et al., } \\
\text { 2007; Kosmidou \& Zopunidis, } 2008\end{array}$ \\
\hline $\begin{array}{l}\text { Consumer } \\
\text { Price Index } \\
\quad\left(\mathrm{X}_{10}\right)\end{array}$ & CPI & Annual CPI & Short, 1979; Gul, Irshad \&Zaman, 2011 \\
\hline
\end{tabular}

\subsection{Research Model}

$\operatorname{Model}(\mathrm{A}): \mathrm{ROA}_{\mathrm{it}}=\alpha+\mathrm{X}_{1} \mathrm{~B}_{1}+\mathrm{X}_{2} \mathrm{~B}_{2}+\mathrm{X}_{3} \mathrm{~B}_{3}+\mathrm{X}_{4} \mathrm{~B}_{4}+\mathrm{X}_{5} \mathrm{~B}_{5}+\mathrm{X}_{6} \mathrm{~B}_{6}+\mathrm{X}_{7} \mathrm{~B}_{7}+\mathrm{X}_{8} \mathrm{~B}_{8}$ $+\mathrm{X}_{9} \mathrm{~B}_{9}+\mathrm{X}_{10} \mathrm{~B}_{10}+\mu_{\mathrm{it}}$

Model (B): $\mathrm{ROE}_{\mathrm{it}}=\alpha+\mathrm{X}_{1} \mathrm{~B}_{1}+\mathrm{X}_{2} \mathrm{~B}_{2}+\mathrm{X}_{3} \mathrm{~B}_{3}+\mathrm{X}_{4} \mathrm{~B}_{4}+\mathrm{X}_{5} \mathrm{~B}_{5}+\mathrm{X}_{6} \mathrm{~B}_{6}+\mathrm{X}_{7} \mathrm{~B}_{7}+\mathrm{X}_{8} \mathrm{~B}_{8}$ $+\mathrm{X}_{9} \mathrm{~B}_{9}+\mathrm{X}_{10} \mathrm{~B}_{10}+\mu_{\mathrm{it}}$ 
Model (C): $\mathrm{EPS}_{\mathrm{it}}=\alpha+\mathrm{X}_{1} \mathrm{~B}_{1}+\mathrm{X}_{2} \mathrm{~B}_{2}+\mathrm{X}_{3} \mathrm{~B}_{3}+\mathrm{X}_{4} \mathrm{~B}_{4}+\mathrm{X}_{5} \mathrm{~B}_{5}+\mathrm{X}_{6} \mathrm{~B}_{6}+\mathrm{X}_{7} \mathrm{~B}_{7}+\mathrm{X}_{8} \mathrm{~B}_{8}+$ $\mathrm{X}_{9} \mathrm{~B}_{9}+\mathrm{X}_{10} \mathrm{~B}_{10}+\mu_{\mathrm{it}}$

Where;

$\mathrm{Y}_{\mathrm{it}}$ represents ROA, ROE and EPS for bank $\mathrm{i}$ at time $\mathrm{t}$.

$\mathrm{X}_{1}$ represents natural logarithm of Total Asset (SIZE) for bank $\mathrm{i}$ at time $\mathrm{t}$

$\mathrm{X}_{2}$ represents Total Liability to Total Equity(GR) for bank i at time $\mathrm{t}$

$\mathrm{X}_{3}$ represents Total Nonperforming Loans to Total loans(NPL) for bank $\mathrm{i}$ at time $\mathrm{t}$

$\mathrm{X}_{4}$ represent Total Liabilities to Total Equity(AC) for bank i at time $\mathrm{t}$

$\mathrm{X}_{5}$ represents Operating Income to Assets(AM) for bank i at time $\mathrm{t}$

$\mathrm{X}_{6}$ represents Operating Expenses to Total Assets(OE) for bank i at time $\mathrm{t}$

$\mathrm{X}_{7}$ represents Total Deposits to Total Assets (DR)for bank I at time $\mathrm{t}$

$\mathrm{X}_{8}$ represents Tier I Capital + Tier II Capital to Risk Weighted Assets(CA) for bank $\mathrm{i}$ at time $\mathrm{t}$

$\mathrm{X}_{9}$ represents Annual GPD (GDP) for bank i at time $\mathrm{t}$

$\mathrm{X}_{10}$ represents Annual CPI(CPI) for bank i at time t

$\mathrm{i}=1$ to 5 banks

$t=2007-2014$

$\mu=$ Error term

\subsection{Research Framework}

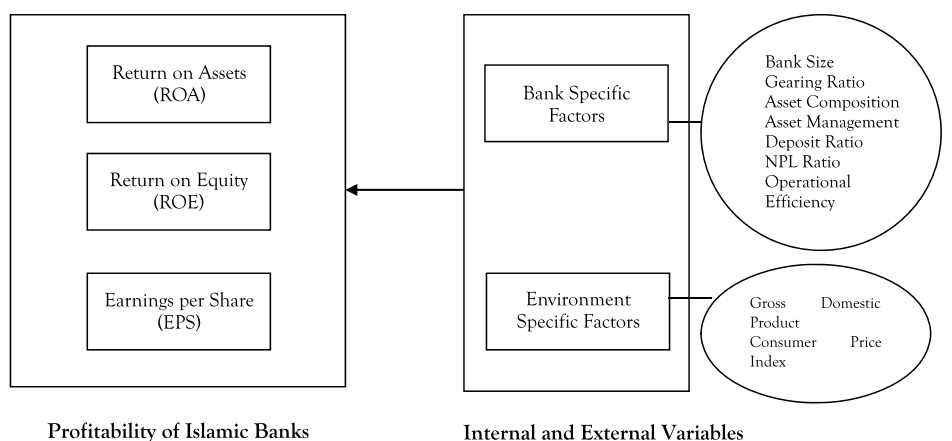




\section{Results and Analysis}

\subsection{Descriptive Statistics}

Table 2 reports the descriptive statistics of all the dependent and independent variables. The value of mean in row one depicts the average of the given variables taken for the study. Standard error is the average dispersion inherent in large number of samples. The volatility in the data set is measured through the standard deviation.

Table 2: Descriptive Statistics

\begin{tabular}{|c|c|c|c|c|c|}
\hline & Mean & $\begin{array}{c}\text { Standard } \\
\text { Error }\end{array}$ & $\begin{array}{c}\text { Standard } \\
\text { Deviation }\end{array}$ & Kurtosis & Skewness \\
\hline ROA $\left(\mathrm{Y}_{1}\right)$ & 0.26 & 0.11 & 0.68 & 2.31 & 0.39 \\
\hline $\mathrm{ROE}\left(\mathrm{Y}_{2}\right)$ & 4.23 & 1.31 & 8.31 & 1.61 & 1.50 \\
\hline EPS $\left(\mathrm{Y}_{3}\right)$ & 0.27 & 0.22 & 1.38 & 1.41 & 1.02 \\
\hline SIZE $\left(\mathrm{X}_{1}\right)$ & 7.56 & 0.08 & 0.48 & $(0.21)$ & $(0.28)$ \\
\hline $\mathrm{GR}\left(\mathrm{X}_{2}\right)$ & 7.42 & 0.77 & 4.84 & $(1.09)$ & 0.31 \\
\hline $\mathrm{NPL}\left(\mathrm{X}_{3}\right)$ & 1.35 & 0.18 & 1.16 & 1.18 & 1.15 \\
\hline $\mathrm{AM}\left(\mathrm{X}_{4}\right)$ & $0.00)$ & 0.00 & 0.02 & $(0.06)$ & $(0.83)$ \\
\hline $\mathrm{OE}\left(\mathrm{X}_{5}\right)$ & 0.02 & 0.00 & 0.01 & 9.68 & 2.05 \\
\hline $\mathrm{CA}\left(\mathrm{X}_{6}\right)$ & 0.25 & 0.02 & 0.15 & $(0.23)$ & 1.04 \\
\hline $\mathrm{DR}\left(\mathrm{X}_{7}\right)$ & 0.72 & 0.03 & 0.20 & 2.75 & $(1.54)$ \\
\hline $\mathrm{AM}\left(\mathrm{X}_{8}\right)$ & 0.87 & 0.04 & 0.26 & 2.93 & 1.07 \\
\hline $\operatorname{LnGDP}\left(\mathrm{X}_{9}\right)$ & 26.65 & 0.29 & 1.82 & $(0.59)$ & 1.20 \\
\hline $\operatorname{LnCPI}\left(\mathrm{X}_{10}\right)$ & 4.51 & 0.04 & 0.28 & $(1.36)$ & $(0.21)$ \\
\hline
\end{tabular}

A small value of standard deviation means that the data points lie close to the mean value. Skewness measures the direction and degree of asymmetry in the variables. A variable with skewness close or equal to zero has a normal distribution. As the value of all variables is close to zero, it shows that data is normally distributed. Similarly, a normal distribution has a kurtosis value of three. To overcome the issue of normality in GDP and CPI, the study takes logarithm of GDP and CPI after applying the test of Normality (Table - 3).

The significance level used for this study is 0.05 with a confidence level of $95 \%$.

\subsection{Correlation Analysis}

Table 4 shows the Pearson correlation test of all the independent variables used 
Table 3: Tests of Normality

\begin{tabular}{|c|c|c|c|c|c|c|}
\hline \multirow{2}{*}{ Variable } & \multicolumn{3}{|c|}{ Kolmogorov-Smirnov } & \multicolumn{3}{c|}{ Shapiro-Wilk } \\
\cline { 2 - 7 } & Statistic & $\mathrm{df}$ & Sig. & Statistic & df & Sig. \\
\hline ROA $\left(\mathrm{Y}_{1}\right)$ & .196 & 12 & .200 & .916 & 12 & .476 \\
\hline ROE $\left(\mathrm{Y}_{2}\right)$ & .211 & 12 & .200 & .920 & 12 & .507 \\
\hline EPS $\left(\mathrm{Y}_{3}\right)$ & .250 & 12 & .200 & .895 & 12 & .346 \\
\hline SIZE $\left(\mathrm{X}_{1}\right)$ & .219 & 12 & .200 & .878 & 12 & .259 \\
\hline GR $\left(\mathrm{X}_{2}\right)$ & .152 & 12 & .200 & .963 & 12 & .840 \\
\hline $\mathrm{NPL}\left(\mathrm{X}_{3}\right)$ & .299 & 12 & .101 & .810 & 12 & .073 \\
\hline AM $\left(\mathrm{X}_{4}\right)$ & .310 & 12 & .073 & .833 & 12 & .114 \\
\hline $\mathrm{OE}\left(\mathrm{X}_{5}\right)$ & .191 & 12 & .200 & .906 & 12 & .412 \\
\hline $\mathrm{CA}\left(\mathrm{X}_{6}\right)$ & .204 & 12 & .200 & .918 & 12 & .493 \\
\hline $\mathrm{DR}\left(\mathrm{X}_{7}\right)$ & .287 & 12 & .134 & .782 & 12 & .040 \\
\hline $\mathrm{AM}\left(\mathrm{X}_{8}\right)$ & .242 & 12 & .200 & .839 & 12 & .129 \\
\hline $\mathrm{GDP}\left(\mathrm{X}_{9}\right)$ & .399 & 12 & .003 & .719 & 12 & .010 \\
\hline $\mathrm{CPI}\left(\mathrm{X}_{10}\right)$ & .459 & 12 & .000 & .551 & 12 & .000 \\
\hline
\end{tabular}

in the study. The test indicates the absence of multi-collinearity among all variables. All the variables show correlation value of less than 0.5 among each other, indicating a low level of multi-collinearity among variables. The results show that the data can be utilized for the regression because the problems do not exist among its variables.

Table 4: Correlation Matrix

\begin{tabular}{|c|c|c|c|c|c|c|c|c|c|c|}
\hline & $\mathrm{X}_{1}$ & $\mathrm{X}_{2}$ & $\mathrm{X}_{3}$ & $\mathrm{X}_{5}$ & $\mathrm{X}_{6}$ & $\mathrm{X}_{8}$ & $\mathrm{X}_{7}$ & $\mathrm{X}_{4}$ & $\mathrm{X}_{9}$ & $\mathrm{X}_{10}$ \\
\hline SIZE $\left(\mathrm{X}_{1}\right)$ & 1.00 & & & & & & & & & \\
\hline $\mathrm{GR}\left(\mathrm{X}_{2}\right)$ & 0.54 & 1.00 & & & & & & & & \\
\hline $\mathrm{NPL}\left(\mathrm{X}_{3}\right)$ & 0.24 & 0.11 & 1.00 & & & & & & & \\
\hline $\mathrm{AM}\left(\mathrm{X}_{4}\right)$ & 0.43 & 0.50 & $(0.15)$ & 1.00 & & & & & & \\
\hline $\mathrm{OE}\left(\mathrm{X}_{5}\right)$ & $(0.43)$ & $(0.47)$ & 0.01 & $(0.43)$ & 1.00 & & & & & \\
\hline $\mathrm{CA}\left(\mathrm{X}_{6}\right)$ & $(0.33)$ & $(0.37)$ & $(0.04)$ & $(0.33)$ & 0.21 & 1.00 & & & & \\
\hline $\mathrm{DR}\left(\mathrm{X}_{7}\right)$ & 0.47 & 0.51 & $(0.01)$ & 0.45 & $(0.18)$ & $(0.63)$ & 1.00 & & & \\
\hline AM $\left(\mathrm{X}_{8}\right)$ & 0.02 & 0.19 & $(0.18)$ & 0.32 & $(0.08)$ & $(0.44)$ & 0.54 & 1.00 & & \\
\hline $\begin{array}{c}\text { LnGDP } \\
\left(\mathrm{X}_{9}\right)\end{array}$ & $(0.59)$ & $(0.46)$ & $(0.36)$ & 0.10 & 0.16 & 0.42 & $(0.35)$ & 0.05 & 1.00 & \\
\hline $\begin{array}{c}\text { LnCPI } \\
\left(\mathrm{X}_{10}\right)\end{array}$ & 0.33 & 0.69 & 0.07 & 0.06 & $(0.24)$ & $(0.50)$ & 0.33 & 0.06 & $(0.39)$ & 1.00 \\
\hline
\end{tabular}


To reconfirm the multi-collinearity, variance inflation factor (VIF) test is also used as shown in Table 5. The rule of thumb of VIF test states that VIF value should be less than 10 (Gujarati, 2004). As all the values of VIF shown in the Table 5 below is 10 which means we reject the null hypothesis and conclude that there is no multi-collinearity among explanatory variables.

Table 5: Variance Inflation Factor Test

\begin{tabular}{|c|c|c|}
\hline Variables & VIF & $1 /$ VIF \\
\hline SIZE $\left(\mathrm{X}_{1}\right)$ & 1.51 & 0.662 \\
\hline $\mathrm{GR}\left(\mathrm{X}_{2}\right)$ & 1.51 & 0.662 \\
\hline $\mathrm{NPL}\left(\mathrm{X}_{3}\right)$ & 1.22 & 0.801 \\
\hline $\mathrm{AM}\left(\mathrm{X}_{4}\right)$ & 1.26 & 0.793 \\
\hline $\mathrm{OE}\left(\mathrm{X}_{5}\right)$ & 1.09 & 0.916 \\
\hline $\mathrm{CA}\left(\mathrm{X}_{6}\right)$ & 1.08 & 0.919 \\
\hline $\mathrm{DR}\left(\mathrm{X}_{7}\right)$ & 1.05 & 0.942 \\
\hline $\mathrm{AM}\left(\mathrm{X}_{8}\right)$ & 1.73 & 0.472 \\
\hline $\operatorname{LnGDP}\left(\mathrm{X}_{9}\right)$ & 2.28 & 0.344 \\
\hline $\operatorname{LnCPI}\left(\mathrm{X}_{10}\right)$ & 2.12 & 0.396 \\
\hline
\end{tabular}

\subsection{Regression Analysis}

Panel data provides more accurate inference of model parameters (Kiviet, 1995), controls impact of omitted variables (Heckman, Killingsworth, \& MaCurdy, 1981), generate more accurate predictions (Hsiao, 2003), and analyze non-stationary time series (Binder, Hsiao \& Pesaran, 2005). After testing the correlation test among variables, multiple ordinary least square (OLS) regression has been applied to check the influence of independent variables on dependent variable. The basic estimation strategy is to pool the observations across banks and apply the regression analysis on the pooled sample. The advantage of pooling is that more reliable estimates of the parameters in the model can be obtained. A number of studies support the OLS regression model to measure the impact of different internal and external factors on the banks' profitability (Bashir, 2003; Singh \& Chaudary, 2009; Sufian \& Habibullah, 2009; Gul, Irshad, \& Zaman, 2011; Anber \& Alper, 2011; Dietrich \& Wanzenried, 2011; Akhtar, Ali, \& Sadaqat, 2011; Riaz, 2013). OLS regression is a valid procedure where the relationship between the variables is stable across cross-section units. The study data set gives evidence that Pakistani banks show similar response to cyclical movements, that is why we decided to apply pooled OLS regression method. 
Table 6 to Table 8 presents the OLS regression analyses results for all the three models. The number of observations in each model is 40 . The coefficient for each variable represents the positive or negative impact on the respective dependent variables. Similarly, t-statistic and p-value indicate whether the variables have significant impact on the ROA, ROE and EPS. The R squared value specifies the overall strength of the model. Durbin-Watson test value indicates the autocorrelation and the F-value shows the overall significance of all three models at $5 \%$ level of significance.

It shows that gearing ratio, NPL ratio, asset management ratio, capital adequacy ratio, and operating efficiency have significant positive impact on ROA of Islamic banks. The deposit ratio and CPI have negative impact on ROA, which is similar to the findings of Kim and Kim (1997). The size of bank, loan composition, and GDP exhibit insignificant relationship with profitability of Islamic banks. An important aspect is that CPI has a significant negative impact on banks' profitability. The $\mathrm{R}$ squared value of the model indicates that $71.5 \%$ variation in the ROA is explained by the independent variables. As a rule of thumb, the value of Durbin Watson, which

Table 6: Panel Regression Analysis (Model A)

\begin{tabular}{|c|c|c|c|c|c|}
\hline \multicolumn{6}{|c|}{ Coefficients } \\
\hline \multirow[t]{2}{*}{ Variables } & \multicolumn{2}{|c|}{$\begin{array}{l}\text { Unstandardized Coeffi- } \\
\text { cientsw }\end{array}$} & \multirow{2}{*}{$\begin{array}{c}\text { Standardized Coeffi- } \\
\text { cients } \\
\text { Beta }\end{array}$} & \multirow[t]{2}{*}{$\mathrm{t}$} & \multirow[t]{2}{*}{ Sig. } \\
\hline & B & Std. Error & & & \\
\hline (Constant) & -3.154 & 6.325 & & -.499 & .622 \\
\hline BankSize & 0.101 & 0.672 & .466 & 1.014 & .319 \\
\hline GearingRatio & 0.018 & 0.058 & .724 & 3.842 & .046 \\
\hline NPLsRatios & 0.053 & 0.075 & .216 & 4.544 & .033 \\
\hline Assetmanagement & 14.974 & 5.998 & .302 & 5.831 & .017 \\
\hline OperatingEfficiency & 18.343 & 5.793 & .339 & 2.081 & .011 \\
\hline CapitalAdequacy & 0.019 & 0.990 & .254 & 2.732 & .008 \\
\hline DepositRatio & -0.095 & 0.487 & -.147 & -2.933 & .015 \\
\hline $\begin{array}{l}\text { AssetLoanCompo- } \\
\text { sition } \\
\end{array}$ & -0.260 & 0.455 & .160 & .905 & .373 \\
\hline LnGDP & 0.098 & 0.076 & .146 & .623 & .538 \\
\hline LnCPI & -0.543 & 0.893 & -.416 & -2.482 & .049 \\
\hline R Square & 0.715 & & F Statistic & & 7.266 \\
\hline AdjustedR Square & 0.616 & & Prob (F Stat) & & 0.000 \\
\hline $\begin{array}{l}\text { Standard Error of } \\
\text { Estimate }\end{array}$ & 0.419 & & Durbin-Watson & & 1.674 \\
\hline
\end{tabular}


is close to 2 , shows no autocorrelation between the variables.

Model B: The regression results of model B are shown in Table 7. The findings suggest that the gearing ratio, NPL ratio, CPI, and asset management have a positive and significant impact on ROE at the $5 \%$ level of significance, whereas deposit ratio has a negative but statistically significant relation with the ROE. Bank size, operational efficiency, GDP, and capital adequacy are found to be statistically insignificant. The $\mathrm{R}$ squared value of the model indicates that $74.2 \%$ variation in the $\mathrm{ROE}$ is explained by the independent variables. Durbin Watson value shows that there is no issue of autocorrelation among variables as value is closer to 2 .

Table 7: Panel Regression Analysis (Model B)

\begin{tabular}{|c|c|c|c|c|c|}
\hline \multicolumn{6}{|c|}{ Coefficients } \\
\hline \multirow[t]{2}{*}{ Model } & \multicolumn{2}{|c|}{$\begin{array}{l}\text { Unstandardized Coeffi- } \\
\text { cients }\end{array}$} & \multirow{2}{*}{$\begin{array}{c}\text { Standardized Coeffi- } \\
\text { cients }\end{array}$} & \multirow[t]{2}{*}{$\mathrm{t}$} & \multirow[t]{2}{*}{ Sig. } \\
\hline & B & Std. Error & & & \\
\hline (Constant) & -51.823 & 72.470 & & -.715 & .480 \\
\hline BankSize & -0.977 & 7.010 & .580 & 1.353 & .186 \\
\hline GearingRatio & -0.345 & 0.611 & .623 & 5.699 & .000 \\
\hline NPLsRatios & 1.034 & 0.784 & .280 & 2.539 & .041 \\
\hline Asset management & 137.241 & 62.499 & .249 & 3.623 & .015 \\
\hline Operating Efficiency & 103.815 & 60.359 & .160 & 1.381 & .178 \\
\hline Capital Adequacy & 2.334 & 10.324 & .256 & 1.172 & .251 \\
\hline Deposit Ratio & -3.380 & 5.079 & -.201 & -3.369 & .018 \\
\hline $\begin{array}{l}\text { AssetLoanCompo- } \\
\text { sition } \\
\end{array}$ & 0.711 & 4.749 & .181 & 1.097 & .282 \\
\hline LnGDP & 1.416 & 0.797 & .179 & .816 & .421 \\
\hline LnCPI & 17.594 & 9.308 & -.419 & -3.603 & .012 \\
\hline R Square & 0.742 & & F Statistic & & 9.755 \\
\hline Adjusted R Square & 0.666 & & Prob(F Stats) & & 0.000 \\
\hline $\begin{array}{l}\text { Standard Error of } \\
\text { the Estimate }\end{array}$ & 4.810 & & Durbin-Watson & & 1.664 \\
\hline
\end{tabular}

Model C: The results of OLS regression of model $\mathrm{C}$ are shown in Table 8. It shows that gearing ratio, asset management composition, NPL ratio, and asset loan composition have significant positive impact on EPS. All other variables have statistically insignificant impact on the EPS. The findings also show that GDP, CPI, and deposit ratio have negative association with the EPS, contradicting the findings of 
Ali, Akhtar, and Ahmed (2011). The R squared value of the model indicates that $76.4 \%$ variation in the EPS is explained by the independent variables. A Durbin Watson value shows that there is no issue of autocorrelation among the variables as the value is closer to 2 .

The reduction in operating expenses and unnecessary personnel expenses improve the operating efficiency of banks and it leads to improve the rate of returns of assets as well as rate of returns of equity significantly. Thus, in order to boost up the profitability of banks, policy makers should lessen the needless operating expense(s) and personnel expense(s) and also optimize the performance of employees so that the cost of funds including services and others may be reduced which results in contracting gap between expenses and income. Islamic banks should use vital tools to increase their profitability by increasing their financings and investments (Total Assets) and by offering competitive rates. Financing and investments' basic source comes from deposits which may be attracted on cheap rates through effective management.

Table 8: Panel Regression Analysis (Model C)

\begin{tabular}{|c|c|c|c|c|c|}
\hline \multicolumn{6}{|c|}{ Coefficients } \\
\hline \multirow[t]{2}{*}{ Model } & \multicolumn{2}{|c|}{$\begin{array}{l}\text { Unstandardized Coeffi- } \\
\text { cients }\end{array}$} & \multirow{2}{*}{$\begin{array}{c}\text { Standardized Coeffi- } \\
\text { cients } \\
\text { Beta }\end{array}$} & \multirow[t]{2}{*}{$\mathrm{t}$} & \multirow[t]{2}{*}{ Sig. } \\
\hline & B & Std. Error & & & \\
\hline (Constant) & -1.294 & 11.709 & & -.111 & .913 \\
\hline BankSize & 1.151 & 1.192 & .403 & .965 & .342 \\
\hline GearingRatio & .130 & .102 & .458 & 1.281 & .021 \\
\hline NPLsRatios & .117 & .151 & .099 & 8.774 & .004 \\
\hline Assetmanagement & 42.357 & 11.737 & .541 & 3.609 & .001 \\
\hline OperatingEfficiency & 4.002 & 10.508 & .043 & .381 & .706 \\
\hline CapitalAdequacy & 3.336 & 2.022 & .352 & 1.650 & .110 \\
\hline DepositRatio & -.606 & .983 & -.088 & -2.616 & .043 \\
\hline $\begin{array}{l}\text { AssetLoanCompo- } \\
\text { sition } \\
\end{array}$ & .888 & .843 & .169 & 1.053 & .030 \\
\hline LnGDP & -.081 & .161 & -.107 & -.501 & .620 \\
\hline LnCPI & -1.611 & 1.259 & -.326 & -4.280 & .011 \\
\hline R Square & 0.764 & & F Statistic & & 9.385 \\
\hline AdjustedR Square & 0.683 & & Prob (F Stats) & & 0.000 \\
\hline $\begin{array}{l}\text { Standard Error of } \\
\text { the Estimate }\end{array}$ & 0.766 & & Durbin-Watson & & 1.638 \\
\hline
\end{tabular}




\section{Conclusion}

The objective of this study was to investigate the determinants of Islamic banks' profitability in the context of Pakistan. The study found that profitability depends upon different bank-specific factors and external factors. The results show that return on assets (ROA) depends on the leverage ratio, deposit ratio, operating efficiency, capital adequacy ratio, NPL ratio, asset management and CPI. Therefore, these factors need attention to develop a sound structure to control ROA. Managers need to focus on these factors too while making strategies. Similarly, ROE and EPS were found to be significantly related to leverage (gearing) ratio, CPI, NPL ratio, deposit ratio, and asset management ratio. EPS is influenced greatly by the asset loan composition.

The current research is limited to only five Islamic banks of Pakistan and is not applicable to other countries' Islamic banks. Further research can be done by comparing the Islamic banking system to the conventional banking stream. Apart from this, it could further be improved if a comparison is made with other countries' Islamic banking systems and its usefulness be provided to the target audience. Also, an increase in number of years (time duration) could help in application of other statistical and econometric analyses, like Fixed or Random effect models, generalized method of movements, etc.

\section{References}

Abreu, M., \& Mendes, V. (2002). Commercial bank interest margins and profitability: Evidence for some EU countries. In Pan-European Conference Jointly Organized by the IEFS-UK E University of Macedonia Economic $\mathcal{E}$ Social Sciences, Thessaloniki, Greece, May (pp. 17-20).

Abu Hussain, H., \& Al-Ajmi, J. (2012). Risk management practices of conventional and Islamic banks in Bahrain. The Journal of Risk Finance, 13(3), 215-239.

Aburime, T. U. (2010). Impact of corruption on bank profitability in Nigeria. EuroEconomica, 23(2).

Akhtar, M. F., Ali, K., \& Sadaqat, S. (2011). Factors influencing the profitability of Islamic banks of Pakistan. International Research Journal of Finance and Economics, 66, 125-132.

Ali, K., Akhtar, M. F., \& Ahmed, H. Z. (2011). Bank-specific and macroeconomic indicators of profitability-empirical evidence from the commercial banks of Pakistan. International Journal of Business and Social Science, 2(6), 235-242.

Alkassim, F. A. (2005). The profitability of islamic and conventional banking in the GCC countries: A comparative study. Journal of Review of Islamic Economics, 13(1), 5-30.

Almazari, A. A. (2014). Impact of internal factors on bank profitability: Comparative study between 
Saudi Arabia and Jordan. Journal of Applied Finance E⿱ Banking, 4(1), 125-140.

Al-Tamimi, H. A. H. (2005). Factors influencing individual investor behavior: An empirical study of the UAE financial markets. The Business Review, 5(2), 225-233.

Anbar, A., \& Alper, D. (2011). Bank specific and macroeconomic determinants of commercial bank profitability: Empirical evidence from Turkey. Business and Economics Research Journal, 2(2), 139-152.

Athanasoglou, P. P., Delis, M. D., \& Staikouras, C. K. (2006). Determinants of bank profitability in the South Eastern European region. Athens, Greece.

Bashir, A. H. M. (2003). Determinants of profitability in Islamic banks: Some evidence from the Middle East. Islamic economic studies, 11(1), 31-57.

Berger, P. G., \& Ofek, E. (1995). Diversification's effect on firm value. Journal of Financial Economics, 37(1), 39-65.

Binder, M., Hsiao, C., \& Pesaran, M. H. (2005). Estimation and inference in short panel vector autoregressions with unit roots and cointegration. Econometric Theory, 21(04), 795-837.

Bourke, P. (1989). Concentration and other determinants of bank profitability in Europe, North America and Australia. Journal of Banking E⿱乛F Finance, 13(1), 65-79.

Brigham, E. F., \& Houston, J. F. (2009). Fundamentals of financial management. Thomson South-Western. Mason, Ohio.

Burki, A. A., \& Niazi, G. S. K. (2010). Impact of financial reforms on efficiency of state-owned, private and foreign banks in Pakistan. Applied Economics, 42(24), 3147-3160.

Chirwa, E.W. (2003). Determinants of commercial banks' profitability in Malawi: A cointegration approach. Applied Financial Economics, 13, 565-77

Demirguc-Kunt, A., \& Huizinga, H. (1999). Determinants of commercial bank interest margins and profitability: some international evidence. The World Bank Economic Review, 13(2), 379-408.

Dietrich, A., \& Wanzenried, G. (2011). Determinants of bank profitability before and during the risis: Evidence from Switzerland. Journal of International Financial Markets, Institutions and Money, 21(3), 307-327.

Flamini, V., Schumacher, L., \& McDonald, C. A. (2009). The determinants of commercial bank profitability in Sub-Saharan Africa. International Monetary Fund.

Goddard, J., Molyneux, P., \& Wilson, J. O. (2004). The profitability of European banks: A cross-sectional and dynamic panel analysis. The Manchester School, 72(3), 363-381.

Gujarati, D. N. (2004). Basic Econometrics, (4th ed.). McGraw Hill.

Gul, S., Irshad, F., \& Zaman, K. (2011). Factors affecting bank profitability in Pakistan. The Romanian 
Economic Journal, 39(14), 61-89.

Haslem, J. A. (1968). A statistical analysis of the relative profitability of commercial banks. The Journal of Finance, 23(1), 167-176.

Hassan, M. K., \& Bashir, A. H. M. (2003, December). Determinants of Islamic banking profitability. In 10th ERF Annual Conference, Morocco (pp. 16-18).

Heckman, J. J., Killingsworth, M., \& MaCurdy, T. (1981). Empirical evidence on static labour supply models: A survey of recent developments. The economics of the labour market, 75-122.

Hsiao, C. (2003). Analysis of panel data. Econometric Society Monographs, 3.

Hsiao, C. (2007). Panel data analysis-advantages and challenges. Test, 16(1), 1-22.

Ijaz, F., Akmal, A., \& Gillani, S. H. B. (2015). The determinants of the Pakistan islamic banking industry profitability: Panel evidence. Islamic Banking and Finance Review, 1(02).

Iqbal, M., \& Molyneux, P. (2004). Thirty years of islamic banking: History, performance and prospects. Springer.

Kim, M., \& Kim, I. W. (1997). The structure-profit relationship of commercial banks in South Korea and the United States: A comparative study. Multinational Business Review, 5(2), 81-94.

Kiviet, J. F. (1995). On bias, inconsistency, and efficiency of various estimators in dynamic panel data models. Journal of Econometrics, 68(1), 53-78.

Kosmidou, K., \& Zopounidis, C. (2008). Measurement of bank performance in Greece. South Eastern Europe Journal of Economics, 6(1), 79-95.

Lin, S.Y. (1988). Bank productivity in Malaysia, Bank Negara Malaysia, Quarterly Bulletin 3, Kuala Lumpur.

Lloyd-Williams, D. M., Molyneux, P., \& Thornton, J. (1994). Market structure and performance in Spanish banking. Journal of Banking $\mathcal{E}$ Finance, 18(3), 433-443.

Molyneux, P., \& Thornton, J. (1992). Determinants of European bank profitability: A note. Journal of banking $\mathcal{E}$ Finance, 16(6), 1173-1178.

Naceur, S.B. \& Goaied M. (2001). The determinants of the Tunisisian deposit banks' performance. Applied Financial Economics, (11), 317-319.

Olson, D., \& Zoubi, T. A. (2011). Efficiency and bank profitability in MENA countries. Emerging Markets Review, 12(2), 94-110.

Ostadi, H., \& Monsef, N. (2014). Assessing the impact of bank concentration and liquidity of Refah Bank branches on profitability during the period 1383-190. International Journal of Human Resource Studies, 4(1), 248-258. 
Raza, Sr. H. (2010). The impact of financial performance of the company on its share price; evidence from Pakistan Stock Exchange. Pakistan: Research Gate publications.

Riaz, S. (2013). Profitability determinants of commercial banks in Pakistan. Paper presented at the 6th international Business and Social Sciences research Conference. Dubai, UAE.

Short, B. K. (1979). The relation between commercial bank profit rates and banking concentration in Canada, Western Europe, and Japan. Journal of Banking $\mathcal{G}$ Finance, 3(3), 209-219.

Siddiqui, A. (2008). Financial contracts, risk and performance of Islamic banking. Managerial Finance, 34(10), 680-694.

Singh, R. K., \& Chaudhary, S. (2009). Profitability determinants of banks in India. International Journal of Global Business, 2(1), 163-180.

Smirlock, M. (1985). Evidence on the (non) relationship between concentration and profitability in banking. Journal of money, credit and Banking, 17(1), 69-83.

Sufian, F., \& Habibullah, M. S. (2009). Bank specific and macroeconomic determinants of bank profitability: Empirical evidence from the China banking sector. Frontiers of Economics in China, 4(2), 274-291.

Uddin, M. B. (2009). Determinants of market price of stock: A study on Bank Leasing and Insurance companies of Bangladesh. Journal of Modern Accounting and Auditing, 5(7), 1-6.

Wum, Hsiu-Ling, Chen, Chien-Hsun, Shiu, \& Fang-Ying (2007). The impact of financial development and bank characteristics on the operational performance of commercial banks in the Chinese transitional economy. Journal of Economic Studies, 34(5), 401-414. 